\title{
A peregrinação política e amorosa de Baltasar Bustos ${ }^{1}$
}

\author{
Cláudia Mentz Martins ${ }^{2}$
}

\begin{abstract}
This essay proposes the analysis of La campaña, by Carlos Fuentes, about a millenarianism perspective. The spaces, wich the protagonist, Baltasar Bustos, goes through as well as his relationship between the other characters and the way he looks himself along the narrative are aspects who deserve our closer look. Also the end of the Busto's journey recieves our attention, because it's possible to interprete his history like interconnnect to the Latin-American people and, thus identify in both periods the same persuit of happiness, the disappointment of their desires and the waiting for new facts.
\end{abstract}

Keywords: La campaña, Carlos Fuentes, millenarianism, Latin-American literature

Resumo: Este texto propõe a análise da obra La campaña, de Carlos Fuentes, sob a perspectiva da doutrina do milenarismo. Os espaços pelos quais o protagonista, Baltasar Bustos, transita bem como seu relacionamento com as demais personagens e o modo como ele se vê ao longo da narrativa são aspectos que merecem nosso olhar atento. Também o término da jornada de Bustos recebe nossa atenção, pois é possível interpretar sua história como interligada a do povo latino-americano, e assim, identificar em ambos os mesmos períodos de busca da felicidade, de frustração de seus desejos e de tempo de espera por novos acontecimentos.

Palavras-chave: La campaña, Carlos Fuentes, milenarismo, literatura latino-americana

É a felicidade que te prometo. Ela é da Terra, e havemos de achá-la... Quando vier a luz, encontraremos outros homens, outro mundo, e aí... É a felicidade...

Vem, vem... Graça Aranha

1 Este texto, em sua origem e com algumas modificações, é uma pequena parcela de nossa tese de doutoramento intitulada Sonhos e quimeras: o milenarismo em narrativas brasileiras e hispano-americanas, apresentada na Faculdade de Letras, PUCRS, em 2004.

2 PRODOC no Instituto de Letras da UFRGS 
A obra La campaña, ${ }^{3}$ de Carlos Fuentes, ${ }^{4}$ narra a vida de Baltasar Bustos, abrangendo um período de dez anos de sua vida, a partir de 1810. Cabe a um de seus melhores amigos, Manuel Varela, contar as campanhas nas quais se engaja, isto é, as lutas pela independência da Argentina e de alguns países da América Latina, ao mesmo tempo em que persegue a bela Ofélia Salamanca.

Essa mulher, pelo menos assim Baltasar crê do início até o final da narrativa, apresenta dois aspectos que a afastam dele: (a) não sabe de sua existência nem da paixão que nutre por ela, e (b) possui posições políticas opostas a ele.

Quando a viu pela primeira vez, Baltasar ensaiava furtivamente a troca dos recémnascidos que realizaria em breve. Seu ato consistia em seqüestrar o filho de Ofélia e do marido, o Marquês de Cabra, substituindo-o por uma criança negra. Porém, ao se exercitar, vislumbrou-a nua, por entre as cortinas, no toucador. A paixão que o tomou foi imediata e absoluta, o que não impediu que, noites adiante, realizasse a ação criminosa e desastrada. Sem se dar conta, quando trocou os bebês, derrubou uma vela no chão, gerando um incêndio incontrolável que matou a criança negra.

Baltasar é um rapaz que tem um relacionamento conflituoso com o pai e com a irmã, mas encontra nos amigos Xavier Dorrego e Manuel Varela ideais comuns, traduzidos numa esperança no futuro. São eles que o incentivam a fazer sua campanha político-amorosa, durante a qual conhece alguns ilustres heróis nacionais - reais ou inventados - e a atriz Gabriela Cóo, que se torna seu novo amor.

As dificuldades por que passa, ao longo de sua jornada, não apenas lhe alteram o físico mas, sobretudo, seu posicionamento ideológico. Baltasar nota a necessidade de ser mais flexível frente a algumas situações para poder sobreviver e a algumas pessoas com as quais deve conviver. Ao longo dos anos, aprendeu a lutar a fim de pôr em prática seu ideal de igualdade, como também precisou conhecer a si próprio, a lidar com suas frustrações, remorsos e desejos.

Ao término de La campaña, Baltasar finalmente encontra-se face a face com Ofélia e descobre não lhe ter afastado o filho recém-nascido, uma culpa que o perseguira ao longo dos dez anos relatados na obra. Fica sabendo que ela era uma revolucionária, mas que agia

3 FUENTES, Carlos. La campaña. México: Fondo de Cultura Económica, 1990. Todas as citações reportamse a essa edição.

4 Carlos Fuentes (Panamá/Panamá, 1928 - ) é novelista, ensaísta e crítico de cinema. Entre outras atividades foi Embaixador do México, na França (1972-1976); dirigiu, junto com Octavio Paz, a Colección Literaria Obregón; colaborou na Revista Mexicana de Literatura, na qual exerceu o papel de fundador e co-diretor com Emanuel Carballo; e ingressou no Sistema Nacional de Creadores de Arte (SNCA), como criador emérito, em 1994. É considerado um dos escritores mais conhecidos da América Latina, não apenas pela quantidade de textos publicados, mas por ser um dos renovadores da prosa mexicana e um teórico da nova estética, oposta às normas acadêmicas. Suas narrativas possuem um misto de realismo, ficção, humor e fantástico, e estão traduzidas para diversos idiomas. Algumas de suas obras são: Los días enmascarados (1954); La región más transparente (1958); La muerte de Artemio Cruz (1962); Aura (1962); Zona sagrada (1967); Cambio de piel (1967); La nueva novela hispanoamericana (1969); Todos los gatos son pardos (1970); Tiempo mexicano (1971); Terra nostra (1975); La cabeza de la hidra (1978); Gringo Viejo (1985); Cristóbal Nonato (1987); Valiente mundo nuevo (1990); La campaña (1990); Geografía de la novela (1993); Diana o la cazadora solitaria (1994); Nuevo tiempo mexicano (1995); La frontera de cristal (1995); Los años con Laura Díaz (1999); Instinto de Inez (2001); Los cinco soles de México (2000); La silla del águila (2003). La voluntad y la fortuna (2008). Cf. DUVIOLS, Jean-Paul. Dictionnaire culturel de l'Amérique Latine: pays de langue espagnole. Paris: Ellipses, 2000. p. 379; FRANCO, Jean; LEMOGODEUC, Jean-Marie. Anthologie de la litterature hispano-americaine du XXe siècle. Paris: PUF, 1993, p. 48-150; CARLOS Fuentes: estos fueron los palacios. In: Espejo de escritores. Entrevistas feitas por Abel Quesada para The New York Time Magazine. Hanover: del Norte, 1985. p. 81-104; e do site oficial do autor: CARLOS FUENTES: página oficial. [s.d]. <http://www. carlos-fuentes.net.>. Acesso em 23 dez. 2009. 
secretamente, isto é, como espiã, tendo esse trabalho arruinado sua saúde e beleza. Após essas revelações e com o final do encantamento pela ex-bela, Bustos retorna a Buenos Aires, volta a conviver com os amigos porteños, adota a criança que uma vez seqüestrara, e que lhe fora entregue pela própria Ofélia, e une-se a Gabriela.

\section{A campanha e os seus espaços}

Apesar de a narrativa iniciar e terminar em Buenos Aires, esse ambiente quase não aparece, porque é um dos espaços onde Baltasar menos transita. A cidade é lembrada como um local em que o primeiro fundador, Pedro de Mendoza, ${ }^{5}$ e os homens e mulheres, que o acompanhavam e que sobreviveram às adversidades do início, a abandonaram com a certeza de que ali não encontrariam o El Dorado. Meio século depois, a cidade voltou a ser fundada e, novamente, o El Dorado desejado não surgiu das suas terras. O sonho da riqueza fácil mostrou-se ilusório e a necessidade do trabalho imperou entre seus habitantes: "Estaba una ciudad soñada para el oro y ganada para el comercio."

A capital é importante na narrativa porque é nesse espaço que a personagem principal pode aprimorar-se intelectualmente. É em Buenos Aires que Baltasar Bustos convive com Dorrego e Varela, seus companheiros quase inseparáveis. Com eles, compartilha os mesmos gostos literários e os ideais pautados na Revolução Francesa. Sentado no Café de Malcos, Varela lê as cartas que Baltasar lhe envia e tece comentários sobre as atitudes do amigo, apoiando-o a seguir em suas empreitadas. O narrador age como o indivíduo que vê os acontecimentos à distância: situado na Capital, observa o que ocorre no interior do País e nas nações vizinhas.

Se os homens apresentam pouco entrosamento com o ambiente urbano, a relação que têm com o solo é de completa identificação, pois é junto dele que se concentra o desenrolar da ação narrativa. A campanha de Baltasar Bustos se dá sobretudo no interior de diversos países latino-americanos: Chile, Alto Peru — atual Bolívia —, Peru, ainda que, em alguns deles, também freqüente a alta sociedade das capitais. Porém, é no pampa que ele se vincula à terra ao mesmo tempo em que a repele.

O pampa é visto pelos seus moradores como um espaço que os protege de todos os perigos existentes nos grandes centros como, por exemplo, Buenos Aires, devido à distância geográfica que o separa da metrópole. Essa região não se mostra como um lugar privilegiado para se viver, mas resguarda os homens de tudo o que seja estranho ao ambiente, sem os renegar ao abandono e à solidão: "Mediaban veinticuatro leguas entre Buenos Aires y la frontera de la pampa, en Areco, y veinte más a Pergamino, [...] Las noticias llegaban tarde; los viajeros también." 7

A importância do pampa reside no fato de despertar os sentimentos conflitantes que Baltasar tem para com o lugar e para com o pai e a irmã que moram ali. Apesar de deter seu olhar sobre a propriedade paterna — que possui um mirante para vigiar o redor e prevenirse dos ataques do mundo "vasto, indiferente y peligroso" — , suas impressões podem se estender por toda região, uma vez que não há indícios de que as terras de sua família sejam diferentes das demais. Para o protagonista, a terra e a família estão relacionadas de forma indissolúvel, ambas despertam-lhe os sentimentos de amor e ódio.

5 Pedro de Mendoza era militar e, por ordem de Carlos V, chefiou a expedição que partiu da Espanha em 1535 para conquistar o Rio da Prata.

6 FUENTES, Carlos. Op. cit., p. 38.

7 Idem, p. 37.

8 Idem, p. 43. 
O pampa tem, ao mesmo tempo, uma topografia capaz de fazer Baltasar Bustos sonhar enquanto se dirige à casa do pai, por lhe passar a idéia de um território sereno, calmo e infinito, _ "El horizonte estaba siempre presente. Era eterno. También era inalcanzable" — para logo o fazer associar a planície a um ambiente de tormentos, que lhe escuta os pensamentos e penetra em sua consciência carregada de culpa pela morte de uma criancinha. A causa é explicável, afinal, nesses campos, "decía el dicho gaucho, andava metido el Diablo". ${ }^{10}$

Essa ambigüidade manifesta-se porque os espaços ocupados pelos homens, ora bondosos ora cruéis, acabam-lhes assimilando o caráter ambivalente - como o de Baltasar. Ele, que pretendia promover a igualdade entre os diferentes indivíduos, levou involuntariamente à morte aquele que teve um nascimento pobre. Desse modo, o pampa, que pode ser sujeitado aos homens, também os dobra à medida em que os faz ficarem a sós com seus pensamentos. $\mathrm{O}$ diabo não mora entre as coxilhas, mas essas, na sua sucessão infinita, fazem com que os homens entrem em um estado de estupor e a consciência aflore entre aqueles que cometeram algum delito.

Devido à distância que o pampa fica de qualquer outro lugar, ${ }^{11}$ o percurso que Baltasar precisa empreender para chegar à fazenda paterna dá-lhe tempo para refletir sobre seus atos. Entre um e outro pensamento, percebe que os ideais de igualdade, liberdade e fraternidade, tão simples na teoria, são difíceis de serem colocados na prática.

Num jogo de atração e repulsão, Balta — como os amigos também o chamam sente-se seduzido pela planície argentina, desejando harmonizar-se com ela, não só porque nasceu ali e conhece-a muito, mas também porque aprecia Rousseau, que discorre sobre a necessidade de o homem desapegar-se dos itens materiais para desfrutar da natureza, onde poderá ser verdadeiramente feliz. Ao ter contato direto com as pessoas que habitam o campo e visualizar a exploração que causam à terra, desencanta-se com a paisagem, não conseguindo enxergar a pureza e beleza que julgava nela existir. Na verdade, percebe que seus sentimentos não passavam de mera idealização do espaço enquanto a realidade se figura de forma grotesca:

Sin embargo, la alharaca ajena, el sueño de la yeguada matrera, le habían permitido, después de todo, una comunión más cierta, por impedida, que esta soledad a lomo de mula en la que la pampa, sus riachuelos, sus árboles de durazno, sus leguas y más leguas de carcañal, habitadas sólo por avestruces enloquecidas, se le presentaban como otros tantos accidentes sombríos y contrastados. La pampa dejeba de ser el espejo de Dios en la tierra. Ahora, en vez de la comunión tan deseada, todo lo que veía en el horizonte eran problemas, contradicciones, opciones indeseadas, haciéndose todas ellas presentes en su ánimo, sin embargo, tan receptivo. ${ }^{12}$

Os demais territórios latino-americanos por onde anda também são significativos porque, ao percorrê-los, desenvolve sua campanha revolucionária e amorosa. É ao atravessar cada um dos países pelos quais luta e ao superar as dificuldades do caminho que se torna

9 Idem, p. 38.

10 Idem, p. 42.

11 Pouco antes dos movimentos que levariam a Argentina à Independência, o país "era um deserto de bolsões populacionais (Buenos Aires, Córdoba, Tucumán, Salta, Mendonza, etc.), freqüentemente mal interligados." Cf. POMER, Leon. As independências na América Latina. Tradução de Rubens Eduardo Ferreira

Frias. São Paulo: Brasiliense, 1999. p. 95.

12 FUENTES, Carlos Op.cit., p. 40-41. Grifo nosso. 
homem de ação e muda de aparência física. Nessa trajetória, deixa de ser um mero filho de fazendeiro, intelectualizado, rico e idealista para ser um líder respeitado e conhecido em toda a América Latina: "La fama lo precedia". ${ }^{13}$

Em sua jornada, o porteño percorre diversos locais latino-americanos. Ele peregrina pelo Alto Peru, pelos Andes e por Veracruz não apenas para colaborar com os revolucionários que visam à independência dos países da América do Sul, mas porque está no encalço de Ofélia Salamanca.

Apesar de Bustos ter-se apaixonado por Ofélia quando ela morava com o marido na Argentina e de a ter acompanhado à distância pela América do Sul, é no México, na cidade de Veracruz, que se dá o encontro dessas personagens. Esse espaço torna-se importante porque é onde termina a campanha política e amorosa de Baltasar; ao chegar ali, já havia adquirido a estatura de um herói. Ao alcançar essa condição, encontra-se com Ofélia, conhece a verdade sobre o posicionamento político e ideológico da mulher, e vê que ela recuperara o filho recém-nascido.

Em Veracruz, descobre que Ofélia Salamanca sempre foi uma aliada, uma revolucionária como ele, mas que, ao invés de pegar em armas e atuar nas frentes de batalha, agia como espiã. Usando sua beleza — a mesma que o encantou — seduzia os inimigos, obtendo informações que eram utilizadas pelos defensores das independências. Também aí a vê com o filho, a criança que julgara ter afastado dela quando, numa noite de maio de 1810, a trocara por um recém-nascido negro.

Assim, Veracruz é duplamente importante para Bustos porque lhe propicia o último olhar sobre Ofélia - agora uma sombra da beleza do que fora, quebrando o encantamento que lhe lançara —, e simboliza a última etapa do amadurecimento e o início de uma nova vida para ele.

Entretanto, dentre todos os lugares pelos quais Baltasar Bustos passa, o mais expressivo é El Dorado. ${ }^{14}$ Procurado pelas mais diferentes pessoas, ao longo dos séculos, é encontrado e visitado em delírios por ele. Esse local imaginário mostra-se tão significativo, que a narrativa oferece uma narração detalhada da passagem de Bustos por esse espaço.

O El Dorado, de La campaña, apresenta-se todo feito de luz, numa aparência etérea e diáfana. Nele, Bustos sente-se cercado por seres que não vê e dentro de uma cidade que apenas intui existir. Tal como o produto de um sonho ou delírio, não percebe com clareza as formas ao seu redor, vislumbrando imagens (de)formadas por diferentes elementos luminosos que se justapõem como num caleidoscópio. Por só existir em sua imaginação,

13 Idem, p. 183.

$14 \mathrm{O}$ El Dorado é um espaço que faz parte do imaginário ligado às Américas Latina e Central. Nos seus primórdios não correspondia a uma localização geográfica: Na época dos conquistadores, o ouro é o objeto de seu desejo, sendo procurado ao longo de todo o território latino-americano. Algum tempo depois, ao lado do ouro, a prata passou a ser procurada, e esses dois metais foram aqueles carregados ao Velho Mundo, na sua forma bruta ou de utensílios roubados dos habitantes da terra. Os explorados também acreditavam que num vale onde havia um lago de águas verdes cercado de árvores de canela, encontrariam o Homem Dourado, um homem que vivia coberto pelo ouro. Não tardou para que a cobiça modificasse esse mito, transformando-o num país dourado. Não foram poucas as expedições que partiram em busca d' El Dorado ou Eldorado e, a cada uma que falhava, mais o intento de encontrá-lo se acirrava. Com Colombo, por um momento, o El Dorado aparece como uma das feições do Paraíso Terrestre. Cf. NOUHAUD, Dorita. Eldorado. In: BRUNEL, Pierre. (Org.) Dicionário de mitos literários. 2. ed. Tradução de Carlos Sussekind et al. Rio de Janeiro: José Olympio, 1998. p. 315-318. Sobre o El Dorado ver também MAGASICH-AIROLA, Jorge; BEER, Jean-Marc de. As regiões do ouro. In: _. América mágica: quando a Europa da Renascença pensou estar conquistando o Paraíso. Tradução de Regina Vasconcellos. São Paulo: Paz e Terra, 2000. p. 113- 153. 
imprime-lhe o motivo de sua existência, Ofélia Salamanca. A lembrança de seu nome tem o poder de evocar a imagem feminina que ocupa seus sonhos e pensamentos nos últimos tempos:

Los edificios eran producto de la luz, desde las puertas y ventanas hasta los altísimos techos de las torres, los relojes eran de luz, y las calles, grandes trazos luminosos; por las avenidas pasaban veloces carruajes de luz, que parecían impulsados por la luz y dirigidos hacia la luz; y en cada esquina, en cada puerta, en cada techo, la luz escribía mensajes incomprensibles, trazaba letras, signos y figuras, nombres integrados velozmente por una suma vertiginosa de puntos de luz, en un marco que era como un emblema de la luz. Y en ese marco, el rapidísimo tecleo de los puntos luminosos escribió un solo nombre, repetiéndolo en sucesivos fogonazos, hasta imprimirlo en la retina com la permanência de algo grabado en piedra. Y ese nombre era OfÉLIA Salamanca, Ofélia Salamanca, Ofélia Salamanca. ${ }^{15}$

Se em El Dorado os homens depositaram os sonhos de bem-viver e acreditaram na possibilidade de desencadear a felicidade, a presença da amada, para Baltasar, faz-se indispensável nesse lugar. Sem ela, não possui razões suficientes para se engajar nas atividades revolucionárias que passam a lhe fornecer sentido para a vida. A descoberta de El Dorado ocorre quando está inconsciente, ou seja, quando o sonho predomina em sua mente. Se é real ou imaginário, não importa. Interessa que a caminhada de Baltasar por tal espaço funciona como um ritual de passagem e de crescimento. Por ser um ambiente relacionado à imaginação, necessita de pessoas crédulas sobre sua existência, que ainda tenham certa ingenuidade e pureza.

Quando vislumbra El Dorado, Baltasar apresenta tais características. Trata-se de um idealista, que crê na possibilidade de com seu esforço transformar o mundo num lugar melhor de se viver. É um jovem movido pela paixão, por um amor platônico. Seu envolvimento com a causa revolucionária e com os sentimentos que devota à Ofélia Salamanca são tão grandes que sua ingenuidade não é apenas intelectual ou emocional, mas também física. Inexperiente sexualmente, não se entrega a nenhuma mulher, evitando macular seu sentimento por Ofélia, ou seja, é puro também no corpo.

À saída do El Dorado, Baltasar está diferente. No que se refere ao plano ideológico, começa a se dar conta de que as independências dos países latino-americanos seriam insuficientes para o alcance da liberdade, da fraternidade e, principalmente, da igualdade que tanto almejava aos homens. No plano pessoal, durante seu delírio, teve primeira experiência sexual. Portanto, o El Dorado simboliza para Baltasar a perda da credulidade, da ingenuidade e da pureza, justamente os sentimentos necessários para a existência de sua crença:

Pero Baltasar Bustos,[...], no sentió un grito de rechazo, sino algo peor, más insidioso: una náusea parecida a la pérdida de la inocencia, una afirmación, sutil como un veneno, de algo totalmente irracional, mágico, que desmoronaba con unas cuantas imágenes seductoras e inasibles toda la paciente construcción racional del hombre civilizado. ${ }^{16}$

Ir ao El Dorado significou-lhe conhecer um ambiente sonhado por muitos indivíduos

15 FUENTES, Carlos. Op. cit., p. 96.

16 Idem, p. 97. 
e haver freqüentado um dos espaços — ainda que irreal - mais antigos do Novo Mundo. Foi uma experiência ímpar por lhe ter oportunizado a vivência dos sentimentos dos primeiros europeus, isto é, dos homens que acreditaram ser possível o restabelecimento da harmonia primordial entre humanos e a natureza, relação que se havia perdido no Velho Continente, e que se mostrou também impraticável na América:

[Baltasar Bustos] Estaba convencido de que había llegado al pasado más remoto, al origen de todas las cosas, y que este origen mágico, de brujería y engaño, no era el de una perfecta asimilación del hombre con la naturaleza, sino, nuevamente, un divorcio intolerable, una separación que lo hería en lo más seguro de sus convicciones ilustradas. Quería creer en el mito de los orígenes, pero no como mito, sino como realidad de mundo e individuo conciliados. ${ }^{17}$

Baltasar - tal como os antigos heróis civilizadores — sai de seu território conhecido e vive aventuras em terras estranhas. Dirige-se a diferentes localidades, retorna a eras passadas para se aprimorar e poder vencer adversidades que se postarão a sua frente.

Sua infância e adolescência foram vividas no pampa, mas sem privações, pois era filho do fazendeiro. No decorrer da campanha, seu organismo necessita reagir às adversidades topográficas para poder se adequar ao contato com a terra. Mesmo quando se encontra em locais urbanos, como Buenos Aires, possui atitudes e hábitos relacionados aos ideais revolucionários da época, diferenciando-se dos homens que habitam o pampa. Por extensão, Bustos também se afasta dos sentimentos de barbárie que considera pertencentes ao território habitado pelos gaúchos, seres dos quais busca se distinguir constantemente.

Se esses são fortes, ágeis e com poucos conhecimentos externos ao universo em que moram, a aparência de Bustos é oposta à deles, assim como sua curiosidade intelectual é acentuada. Mesmo sem se dar conta, a proximidade com a terra torna-o semelhante a tais homens gerando-lhe sentimentos diversos: de satisfação pelo porte e repúdio pela aproximação dos atos que praticam.

\section{Baltasar, ele e os outros}

A luta pela independência do solo latino-americano possibilita alterações em Baltasar a tal ponto que ele próprio se estranha. Percebe não ser mais um idealista, ao mesmo tempo em que se dá conta de estar próximo do jeito de ser dos gaúchos. A princípio nota isso pela própria aparência física modificada, não observando que sua transformação e similaridade a esses homens vão além, e alcança a maneira de se posicionar frente à vida, isto é, de sua ação estar voltada para a necessidade de sobreviver.

A mudança ocorre sem que ele veja tal processo. O primeiro indício é o de ordem física, com o corpo perdendo o aspecto de uma massa amorfa e ganhando contornos definidos. A intensa atividade física exigida pelos grupos revolucionários, que estão sempre se movimentando, faz com que as elucubrações a que estava acostumado, em Buenos Aires, dêem lugar à ação, ou seja, Baltasar deixa a simples teorização de seus ideais e passa à prática. A inércia faz parte do passado e ele se torna um homem que luta por uma América Latina independente, mais justa e fraterna. Porém, essa transformação física, que reflete seu novo posicionamento, dá-se lentamente, sendo-lhe penosa porque não significa que sua ação alcance o objetivo desejado — o de gerar a igualdade entre todos os seres.

17 Idem, ibidem. 


\section{Conexão Letras}

O olhar de Baltasar, que é míope, aparece referido diversas vezes na narrativa, tendo muito mais um sentido simbólico do que literal. No início da obra, a personagem carrega consigo "la impresión de peso y miopía" 18 numa alusão aos quilos a mais que tem e à visão deficitária. Conforme a ação se desenrola, passa a registrar o fato de não enxergar bem quando escreve a Dorrego e Varela. É como se pedisse desculpas aos amigos por não conseguir explicar os acontecimentos revolucionários.

Segundo Magdalena Perkowska-Alvarez, ${ }^{19}$ o problema visual de Bustos representa sua dificuldade em compreender o mundo. Os conflitos psicológicos que o atormentam provêm da inabilidade de perceber e comparar diferentes elementos concomitantemente, devido ao seu ângulo comprometido:

Estas referencias [sobre el impedimento visual] dejan de denotar y comienzan a connotar apuntando a la incapacidad del personaje de percibir y aprehender el mundo que lo rodea. Siendo miope, Baltasar puede ver sólo de muy acerca; en otras palabras, le faltan la perspectiva y la habilidad de ver varias cosas a la vez y establecer relaciones entre ellas. ${ }^{20}$

Para o protagonista, torna-se sem valor a equação "ver e saber", ${ }^{21}$ pois seu testemunho e suas reflexões sobre a realidade se acham comprometidos. Trata-se quase de uma impossibilidade de se aproximar do verídico, uma cegueira ideológica a partir da qual só percebe as situações que não coloquem em xeque suas convicções e ideais.

Ao se engajar nas lutas revolucionárias, Baltasar confronta-se com suas limitações físicas e militares. Amante das letras e habituado ao meio urbano, apesar de ter nascido e crescido na fazenda do pai, falta-lhe a habilidade de comando e a capacidade de se impor aos homens e ordenar-lhes atos destrutivos:

¿Qué demonios ando haciendo yo, gordo, ciego y enamorado de mis libros, en estas soledades salvajes?

Otros siglos, otros sueños y cuanto los negaba, se presentaron en confusión desbordada en el trayecto de Baltasar Bustos. Los encuentros de armas nunca ocurrieron. El improvisado soldado de la independencia nunca tuvo que ordenar una formación de batalla, y más de una vez la palabra "fuego" se le congelo en la boca. ${ }^{22}$

O interessante é que sua aparência oscila de acordo com a aproximação ou a distância em que se encontra de Ofélia Salamanca. Ao sabê-la longe, vai a seu encalço e adquire um corpo viril, porém, ao acreditar estar perto dela, perde essa feição. Isso talvez aconteça porque, inconscientemente, não deseja a aproximação com a mulher. $\mathrm{O}$ amor e a admiração, acrescentados ao sentimento de culpa por ter-lhe tirado o filho, fazem com que Baltasar não lhe queira parecer atraente, possuindo, assim, uma conduta paradoxal.

18 Idem, p. 26.

19 PERKOWSKA-ALVAREZ, Magdalena. Un realismo censurado: la poética del des/engaño en La campaña de Carlos Fuentes. CRICCAL: les nouveaux réalismes - autre réel, autre écriture. Paris, 2ème série, n. 25, p. 95-103, 4ème trim. 2000.

20 Idem, p. 100.

21 Perkowska-Alvarez afirma que a vista deficiente de Balta pode ser entendida como uma incapacidade do homem em encarar o mundo; "cegado por sus ideas, intereses, miedos o preferências, solamente puede o quiere ver fragmentos, aspectos y, a veces, prefiere no ver". Idem, p. 101.

22 FUENTES, Carlos. Op.cit., p.76. 
Além desses aspectos, a alteração na aparência sugere, para Baltasar, sua aproximação com os gaúchos. Se fisicamente ele e os gaúchos passam a se parecer, dado o porte esbelto e a destreza para executar tarefas braçais, seus estados de espíritos continuam distintos. Enquanto os esses aceitam as imposições dos fazendeiros e lhes servem sem contestação, aquele participa das revoluções que vão contra o sistema governamental estabelecido em diversos países. A subserviência dos gaúchos aos (des)mandos dos patrões faz com que ele os despreze. Afinal, o que ocorre nas fazendas é uma reprodução do sistema feudal, há muito falido na Europa. Os códigos e as atitudes que regem a vida daqueles que habitam a fazenda paterna e os arredores nada têm em comum com seu modo de ser cosmopolita. ${ }^{23}$

O desprezo que sente por todos os gaúchos é destilado contra os homens que prestam serviço a seu pai. Numa primeira ocasião, esse sentimento ocorre porque crê que esses se consideram superiores a ele por possuírem melhor físico. Depois, a aversão se mantém pela passividade com que os homens do campo aceitam imposições dos fazendeiros, praticando atos contrários à ideologia de Baltasar.

O rancor de Bustos para com os gaúchos apresenta-se mais forte ao se sentir inferiorizado, isto é, ver que eles se mostram altivos por serem mais ágeis, conhecerem as lidas do trabalho e desempenhá-las bem, ao contrário do filho do patrão que nem enxergar direito consegue sem o auxílio dos óculos. Baltasar revolta-se ao perceber que sua cultura e seus ideais, dos quais se orgulha, não significam nada para os homens da fazenda, instigando-lhe a executar atos autoritários e despóticos que condena em outras situações. Esquece-se que apregoa a liberdade, a fraternidade e, sobretudo, a igualdade entre todos os homens:

Le gustaba darles órdenes y sentirlos humillados. Su padre se lo criticaba cariñosamente. "La caridad empieza por casa. Si quieres ser justo, comieza con los que te sierven". Pero Baltasar veía en le gauchaje algo similar a una horda de mongoles. [...] Baltasar no imaginaba, simplemente, un futuro con gauchos. [...] Eran los agentes de un holocausto improductivo, que iba dejando el campo regado de cadáveres. Y ofendían aún más la sensibilidad de Baltasar porque eran nómadas, inarraigables, negaciones ambulantes de la vida sedentaria que él identificaba con la civilización. ${ }^{24}$

Seu desprezo por esse grupo social é tão intenso que não hesita em humilhar um dos trabalhadores de seu pai na frente de todos os outros. Mesmo sabendo que, com seu ato, tornará terrível a vida desse homem, nada o impede de agir:

El joven gaucho que le detenía la mano se parecía a Baltasar. Era un Baltasar sucio, barbado, hambriento, aunque saciado de vaca muerta. La cara redonda, la mirada lejana, la cabellera de bucles tornasolados por la intemperie [...]

Baltasar miró a ese gemelo atroz y tuvo la lucidez de devolverle el apretón, tomarle la muñeca al gaucho, levantarle violentamente la manga y revelar las heridas crueles del antebrazo. La educación del campo, bárbara y rechazada, regresó a él y él sentió repugnancia de dejarse vencer por los orígenes detestados $[\ldots]$

[...] Todos lo miraron con desprecio al joven gaucho primero, y con compasión después; y los mismos sentimientos, sólo que invertidos, se los ofrecieron a Baltasar Bustos. $^{25}$

23 Segundo Menton, é possível ver La campaña como uma novela neocriolista, pois tematiza a civilização e a barbárie. Cf. MENTON, Seymour. Crónica de uma guerra denunciada: "La campaña” de Carlos Fuentes. In:__. La nueva novela histórica de la América Latina 1979-1992. México: Fondo de Cultura Económica, 1993.

24 FUENTES, Carlos. Op.cit., p. 44.

25 Idem, p. 53-54. 
A aversão traz um sentido oculto: Baltasar se vê refletido no gaúcho. Inicialmente, o formato do rosto, o olhar distante e os cabelos revoltos e queimados são aspectos que sugerem a parecença entre eles. Depois, reconhece, no outro, características pertencentes a si próprio, isto é, a inabilidade em lidar com armas brancas e a dificuldade de se defender, tendo em vista as cicatrizes no braço daquele a sua frente. A aproximação entre os dois ainda se estende aos sentimentos de compaixão e desprezo que despertam nos homens que servem a José Antonio Bustos. Portanto, por não possuir as habilidades necessárias para viver no pampa - dadas as feridas e a aparência - o gaúcho é um duplo de Bustos que, ao se ver nele, o despreza. ${ }^{26}$ A maneira violenta como ele faz o reconhecimento, aponta que apesar de estar afastado do pampa, a educação que teve aí não se apagou, mas está sempre viva. Mesmo que Baltasar seja um jovem culto, em sintonia com as novas idéias e com a civilização, não há como negar sua origem. A educação informal do campo, os códigos de conduta conhecidos — mas não escritos — por todos os habitantes estão latentes, podendo a qualquer momento, como ocorreu, aflorar e mostrar-lhe que a barbárie ainda está presente no seu espírito.

$\mathrm{O}$ ato intempestivo de Bustos nos faz perceber que ele próprio ainda não consegue agir com fraternidade. O sentimento, apregoado nos livros franceses que lê e que considera essencial para a formação da sociedade que almeja, ${ }^{27}$ está distante de seu comportamento.

Os sentimentos antagônicos de Bustos não são direcionados apenas aos homens que trabalham na fazenda paterna. Com o próprio pai e com a irmã Sabina também desenvolve relações conflituosas, pautadas tanto no amor familiar e no respeito, quanto no ódio e na indiferença.

O pai, José Antonio Bustos, é um típico estancieiro e, ao contrário do filho, que crê ferrenhamente nos ideais franceses, ora julga-os pertinentes, ora totalmente sem propósitos. Portanto, as várias oscilações que caracterizam Baltasar encontram eco no próprio pai: “Si me encuentras muerto con una vela en la mano, quiere decir que acabé por darte la razón. Si me encuentras con las manos cruzadas sobre el pecho y enredadas en un escapulario, significa que me aferré a mis ideas y me morí condenando las tuyas." 28

A presença do escapulário é significativa, pois mostra o apego à religiosidade, isto é, à ordem estabelecida e vigente, em oposição à vela, que — para ele — simboliza a razão, a iluminação, o caminho apontado pelo filho como sendo aquele por onde chegarão as mudanças que se anunciam. Sua morte indica que esse impasse permaneceu até o fim da vida, já que faleceu segurando um escapulário e uma vela. Nem reacionário, nem revolucionário, o pai de Baltasar deixou-lhe como herança a tarefa de provar a si mesmo que a opção pelas independências pode ser o melhor caminho para a felicidade do povo latino-americano.

26 Baltasar demonstra, ao longo de sua trajetória, diferenciar-se do seu duplo pela coragem e pela capacidade de se defender dos adversários. Tal distinção o colocará ao lado das figuras revolucionárias da América Latina, como Miguel Lanza, Pe. Idelfonso de las Muñecas e Pe. Quintana, fazendo-o um contestador da ordem político-social vigente.

27 Segundo Alain Pessin, a fraternidade entre os homens é um item indispensável na obtenção de uma sociedade utópica. Para esse autor, "ela [a Fraternidade] seria de natureza a dissolver as perversões do caminho, a reduzir a pobreza, a preservar a capacidade de nos desenvolvermos a acolher todos os homens, a fazer da tolerância outra coisa que uma marca de butique'. Cf. PESSIN, Alain. Le retour de l'utopie. L'imaginaire utopique aujoud'hui. Paris: PUF, 2001. p. 16. No original: “elle [la Fraternité] serait de nature à dissoudre les perversions de la marche, à réduire la pauvreté, à préserver la capacité de nos environnements à accueillir tous les hommes, à faire de la tolérance autre chose qu'une enseigne de boutique".

28 FUENTES, Carlos. Op. cit., p. 37. 
Esse comportamento titubeante de José Antonio Bustos não aborrece Baltasar, que lhe nota na indecisão a capacidade de não se deixar tomar por paixões. O filho admiralhe o domínio sobre os sentimentos e gostos com o objetivo de visualizar prós e contras com maior clareza. A ausência de radicalismos — que não encontra em nenhum outro companheiro - leva o jovem a procurar o pai e admirar-lhe as atitudes: "Baltasar imaginaba a su padre como un hombre en el umbral entre la vida y la muerte, pero también entre la razón y la sinrazón, entre la independencia y la colonia, entre la revolución y la contrarrevolución."29

Com a irmã Sabina, o relacionamento de Baltasar não é tranqüilo. Ao mesmo tempo em que lhe tem carinho fraternal e a admira por permanecer na fazenda, Baltasar a odeia, mas também sente pena por saber que ela não gosta da vida que leva.

Sabina surge na narrativa como uma personagem que se opõe explicitamente ao irmão, não compartilhando seus ideais e sonhos: "Decide: ¿eres leal a tu familia o a tu revolución?". ${ }^{30}$ Enquanto Bustos simboliza o ser que idealiza um mundo, a irmã representa o apego à vida prática, à necessidade de sobreviver às adversidades do dia-a-dia. Para ela, as mudanças pelas quais Baltasar anseia servem apenas para desestabilizar o mundo, gerando o caos na ordem social que conhece e na qual está bem adaptada: "Tú y tus ideas nos han dejado a la intemperie. Teníamos un refugio: la colonia. Teníamos una protección: la Corona. Teníamos una redención: la Iglesia. Tú y tus ideas nos han dejado a merced de los cuatro vientos. Mira nada más, hermano. ¡Qué daño le hacen los tuyos a los nuestros!"31

À irmã de Bustos não há possibilidades de ilusões porque as adversidades do pampa endureceram-lhe o coração. $\mathrm{O}$ amor e o casamento com o homem amado são, em sua percepção, quimeras de moças casadoiras. Ao contrário de Bustos que sonha com Ofélia, Sabina refere-se aos homens apenas como machos dos quais não espera e nem deseja dar afetos.

$\mathrm{Na}$ época que Baltasar mantinha uma posição apática diante da vida, pautada nos discursos e imprecações contra a política estabelecida, Sabina já era uma mulher de ação. Portanto, o vínculo que estabelecem com a violência também é diferenciado. Para ele, os atos brutais se justificam se forem em prol de uma causa nobre e voltados aos inimigos declarados. Por sua vez, a irmã é perita em lidar com facas. Como está restrita ao universo da fazenda e reprimida pelo pai, não pode ferir a semelhantes a si. A exteriorização de sua brutalidade ocorre então contra aqueles que pode subjugar. $\mathrm{Na}$ impossibilidade de agredir aos homens, lança mão do poder que exerce sobre os cachorros pertencentes à fazenda:

\footnotetext{
Baltasar vio a Sabina manchada de sangre, con un cuchillo en la mano, degollando perros y arrojándolos al zanjón que se llenaba de despojos, y así descubrió Baltasar, viéndola manejar un envenado con la fuerza y destreza de diez hombres que su hermana amaba los cuchillos... [...]

[...] ella se pasó la mano por la boca, se la embarró de sangre y corrió hacia la estancia pero sin abandonar el cuchillo... ${ }^{32}$
}

Os dois irmãos mostram-se, assim, como representantes de duas posições apostas: ele ligado à civilização e ela, à barbárie. As atitudes deles são contrárias às que poderíamos esperar: enquanto Sabina estaria inserida numa esfera ligada à fragilidade, Baltasar, devido a sua condição masculina, tenderia à brutalidade. Porém, é natural que Sabina, por

29 Idem, p. 45.

30 Idem, p. 50.

31 Idem, p. 47.

32 Idem, p. 61 


\section{Conexão Letras}

ser a única mulher na fazenda do pai e por viver no meio dos gaúchos, acabe assumindo atitudes violentas - afinal essa é a maneira que encontrou de impor sua vontade. Já Baltasar, como deseja se afastar do ambiente em que se criou, procura manter-se distante de ações agressivas, preferindo a reflexão sobre as causas e conseqüências dos problemas que despontam a agir na tentativa de solucioná-los.

Se Baltasar e Sabina não conseguem superar suas diferenças, os sentimentos verdadeiramente fraternais encontram vez nos três amigos de Buenos Aires. Baltasar Bustos tem em Manuel Varela e Xavier Dorrego os companheiros com os quais não apenas compartilha a amizade, mas mantém afinidades intelectuais e ideológicas. Com esses dois amigos, ele se corresponde durante sua peregrinação pela América do Sul e dedica-lhes, para seu infortúnio, confiança cega.

Como é Varela quem narra a história, vemos os acontecimentos pelo seu prisma, até porque ocasionalmente ele tece comentários sobre os fatos relatados por Baltasar a partir das cartas que recebe do amigo. O tom fraternal com que trata o protagonista tem dois objetivos: estimular o amigo distante a seguir sua jornada e sensibilizar o leitor para a campanha de Baltasar.

Os três assemelham-se a irmãos tamanho o afeto que os une. A simpatia pelos pensamentos dos iluministas faz com que cada um deles aprecie um dos principais pensadores franceses promovendo, em solo argentino, uma reprodução da cena parisiense:

Dorrego es voltaireano, cree en la razón, pero sólo se la concede a una minoría iluminada capaz de conducir a la masa hacia la felicidad; Bustos es rousseauniano, cree en la pasión que nos lleva a recuperar la verdad natural y a reunir, como en un haz, las leyes de la naturaleza y las de la revolución. Son dos caras del siglo XVIII. Hay una más, la mía, la de Manuel Varela el impresor, que es la máscara sonriente de Diderot, la convicción de que todo cambia constantemente y nos ofrece, en cada momento de la existencia, un repertorio de donde escoger. ${ }^{33}$

La campaña termina sem que Baltasar saiba que seus últimos dez anos foram determinados por esses amigos que dispuseram de sua vida para a realização das propostas revolucionárias. Quem vive a jornada, passa por dificuldades, supera medos e obstáculos é Baltasar, mas tudo isso orquestrado por Dorrego e Varela, sob a desculpa de que dessa maneira ajudavam o hermano menor - como o chamavam - a realizar seu projeto de colocar na prática os ideais franceses:

Nosotros, en la década de nuestra participación revolucionaria, lo animamos desde Buenos Aires, le impusimos aquella comisión en el Alto Perú siguiendo los pasos de Castelli, y lo lanzamos a una vida de peligros y aventuras que Dorrego y yo, pues, ni por asomo vivimos personalmente... ${ }^{34}$

Se considerarmos as adversidades e perigos enfrentados por Balta, durante sua trajetória, a amizade que os amigos lhe devotam é, no mínimo, ambígua. O jovem confia plenamente nos dois, revelando-lhes seus sentimentos, angústias, vitórias e desapontamentos, mas lhes conhece apenas uma face, aquela que eles lhe mostram no Café de Malcos. Por outro lado, Dorrego e Varela não agem de má fé para com Bustos, pois não lhe desejam mal algum, apesar de não serem completamente sinceros com ele, ao lhe

33 Idem, p. 25.

34 Idem, p. 253. Grifo nosso. 
ocultarem o envolvimento que têm na sua peregrinação. O que percebemos é uma maior lealdade no hermano menor, fruto talvez de sua ingenuidade e da alegria de ter encontrado companheiros para seu aprimoramento intelectual.

A camaradagem também se faz presente nos contatos que Bustos estabelece com as diversas personagens envolvidas nas lutas de independência dos países latino-americanos nas quais se engaja. Se Dorrego e Varela são amigos permanentes, Echagüe, Arias, Miguel Lanza, Pe. Ildefonso de las Muñecas e Pe. Quintana - cada um em seu tempo — são companheiros de determinados momentos de sua campanha e fornecem, em parceria com os dois primeiros, o apoio de que Baltasar necessita para dar seguimento a sua jornada. Sem eles e sem as experiências que com eles desfruta, não poderia concluir sua empreitada com sucesso. ${ }^{35}$

Baltasar é um utopista, ao mesmo tempo em que é um indivíduo voltado para o mundo. Ele procura pessoas que estejam a par dos problemas que aflijam os homens, que sejam altruístas e que não se conformem em manter uma estrutura social em que nem todos são felizes, nem vivam harmoniosamente. Portanto, anseia encontrar alguém que tenha o seu desprendimento para auxiliá-lo na sua tarefa de melhorar a sociedade: "O utopista almeja o homem do mundo, isto é, aquele que, contrariamente a ele, alinhe seu passo com o do mundo, um divertimento em que descobre a inteligência e a generosidade."36

Espera que os heróis locais, entre eles Mariano Moreno, transformem a Argentina num grande país, sem participar das ações que desencadeiem as mudanças que almeja. Posteriormente, porém, assume a responsabilidade de também alterar a ordem vigente, deixando a passividade e tornando-se um ser atuante, ao lado de outras pessoas que têm a mesma intenção.

Pe. Ildefonso de las Muñecas e Pe. Quintana são alguns revolucionários que mostram a Bustos que a sociedade igualitária e fraterna que procura constituir é uma utopia. A luta na qual estão engajados visa apenas à alteração do governo, uma vez que a condição social da população não sofrerá melhorias. Eles também lhe fazem ver que o povo, de modo geral, não tem idéia do que de fato ocorre no próprio país. A cena do jovem herói falando para os índios que não o compreendem é exemplar disso:

Vio Baltasar que algunos indios se hincaron, y rápidamente descendió del caballo, les tocó las cabezas cubiertas por la gorra india, a cada uno le fue ofreciendo las manos, [...] — Nunca más, somos iguales, nunca vuelvan a hincarse, esto se acabó, todos somos hermanos, ustedes deben gobernarse a sí mismos, ustedes deben dar el ejemplo, ustedes están más cerca de la naturaleza que nosostros...

El padre De las Muñecas tomó del brazo a Baltazar diciéndole: — Está bien, basta ya, no insistas, has sido escuchado. [...]

- Mentira, padre. No he sido escuchado. ¿Cuántos de estos indios hablan español?

— Muy pocos, casi nadie, es cierto - $[\ldots]^{37}$

35 Segundo Seymour Menton, essa novela está estruturada tanto no ritmo binário quanto ternário para "reflejar la ideología pregonada de flexibilidad y de pluralismo" (p. 246). Através desses ritmos, Fuentes mostra os encontros violentos entre espanhóis e insurgentes; as Guerras de Independência, na América do Sul, nos países de língua espanhola; os confrontos entre liberais e conservadores; as lutas entre governo e guerrilheiros. Ainda segundo Menton, o ritmo binário aparece sobretudo nos amores chilenos de Baltasar Bustos, Ofélia e Gabriela, e no duplo fuzilamento em Veracruz da Virgem de Guadalupe. Já o ritmo ternário está presente nas diversas relações de amizade e companheirismo que Baltasar estabelece ao longo da narrativa. Tais composições são reforçadas pela estrutura do próprio texto, formado ora por dois ora por três elementos: "El ritmo binario/ternario se refueza estilísticamente a través de toda la novela con series de dos o três sustantivos, adjetivos y verbos paralelos". Cf. MENTON, Seymour. Op. cit., p. 248.

36 Cf. PESSIN, Alain. Op. cit., p. 19. No texto original: "L'utopiste procure à l'homme du monde, c'est-à-dire à celui qui, contrairement à lui, aligne sa marche sur celle du monde, un divertissement où il découvre de l'intelligence et de la générosité."

37 FUENTES, Carlos. Op. cit., p. 83-84. 
Provavelmente, a conscientização de Bustos apresenta-se como o momento mais doloroso da campanha, pois percebe que as pessoas por quem luta não o entendem, e que talvez nem compartilhem de seus anseios sociais. A cena também mostra Baltasar como um homem voltado para o mundo desejando tornar a América Latina mais justa a quem o quiser ouvir. ${ }^{38}$

A personagem que ajuda Balta a perceber que a realidade difere daquela que acredita existir é o Pe. de las Muñecas, um revolucionário ${ }^{39}$ desejoso de instaurar uma nova ordem social, mas sem expectativas de a obter no plano terreno como ele próprio expressa: "Allí [en otro mundo] espero encontrar la justicia que acabas de proclamar. No aqui en la tierra. Tu les hablastes de la tierra. Nunca les ha pertencido." ${ }^{40}$ Com seu discurso, o religioso mostra ao rapaz que a independência do Peru, ${ }^{41}$ se obtida, e a transição para a República, pouco mudará a vida dos habitantes locais, uma vez que continuarão à mercê dos donos da terra, isto é, dos crioulos ricos e donos das mitas ou dos latifundiários.

Além disso, é esse sacerdote, que não crê na justiça terrena, que faz com que o porteño perca a virgindade. Falando enquanto um rebelde eclesiástico, como o próprio padre se denominava, propõe um pacto a Baltasar: concorda em colocar na prática os ideais do jovem, em fazer cumprir o discurso proferido aos índios, desde que esse se entregue a uma mulher, já que ele está impedido por voto religioso:

Pues mire, mi teniente porteño, vamos a hacer un trato. Yo le prometo sobre la cabeza de mis doscientos muchachos hacer cumplir sus decretos aunque nos cueste los cojones; pero usted me va a prometer que esta misma noche pierde la virginidad... No se me sonroje, mi teniente. En la cara se le ve, luego luego y desde lejecitos. Qué le parece: yo, la ley; usted, una mujer. O más dicho. Yo su ley. Y usted mi hembra. Os lo asegura un rebelde eclesiástico. ${ }^{42}$

O acordo proposto pelo padre é uma maneira de fazer o jovem ver que a obtenção de mudanças exteriores só é possível quando há transformações no próprio indivíduo. $\mathrm{O}$ sucesso da empreitada política de Bustos será alcançado se houver uma modificação na sua maneira de se posicionar diante do sexo (ou do amor) uma vez que ambas trajetórias estão interligadas.

A vida amorosa de Balta é norteada por um aspecto binário devido à existência de duas amadas chilenas: Ofélia Salamanca, a grande paixão, e Gabriela Cóo, o amor último. Apesar de seu interesse por Gabriela surgir enquanto ainda procura a outra, não há a ocorrência de um triângulo amoroso. Afinal, Ofélia nunca lhe deu qualquer tipo de atenção e, até ao término da campanha, ele acredita ser-lhe um estranho. Reforçando isso, o jovem

38 Baltasar é um homem preocupado com o mundo e não um homem do mundo, se esse for entendido na concepção de Pessin. Para o autor, "o homem do mundo sai a distribuir gratuitamente os sonhos e as falas, a semear a todos os ventos, sem precisar se comprometer, se engajar, se cotizar a justa causa". No original: "L'homme du monde lui sait gré de distribuer gratuitement ses rêves et ses paroles, de semer à tous le vents, sans lui demander de signer, de s'engager, de cotiser à juste cause." Cf. PESSIN, Alain. Op. cit., p. 19. Ou seja, o protagonista difere do homem do mundo ao apresentar um envolvimento sério e comprometido com a causa revolucionária.

39 Durante as lutas pela independência do Peru, Padre Ildefonso de las Muñecas tem presença marcante no grupo organizado pelo Brigadeiro Mateo García Pemacahua, um cacique octogenário, que marcha sobre La Paz. Cf. POMER, Leon. Op. cit., p. 131.

40 FUENTES, Carlos. Op. cit., p. 84.

41 A referência específica a esse país se dá porque foi onde ocorreu a cena em análise. A mesma situação poderia acontecer com qualquer outro povo indígena.

42 FUENTES, Carlos. Op. cit., p. 86. 
só assume seus sentimentos por Gabriela ao concluir sua campanha político-amorosa.

Tal como as relações afetivas instáveis que estabelece com o pai e com a irmã, a que tem com Ofélia não é diferente. Diante dela, ao final da obra, Balta fecha um ciclo de sua vida, isto é, finaliza o período em que passou em campanha, pois o encanto que ela lhe causou se quebra. Ele percebe que não precisa mais carregar a culpa de ter-lhe privado da maternidade, já que a própria mãe havia resgatado o filho. Baltasar também fica ciente de que Ofélia era uma aliada disfarçada, que sacrificou sua saúde e beleza em prol das revoluções de independência. Além disso, descobre que a mulher, que está à beira da morte, sempre teve conhecimento do amor que ele lhe devotava, e que, por isso, será o tutor do filho dela. A situação permite-lhe, então, transferir todo o afeto que sente pela mãe para a criança, cujo bem-estar passa a ser de sua responsabilidade.

Os acontecimentos que envolvem essa mulher não se referem apenas a Baltasar, mas também dizem respeito a Varela. $\mathrm{O}$ amigo, junto com Dorrego, não só interferiu na campanha do hermano, como o manipulou nas questões de ordem sentimental. Sabedor da verdade sobre Ofélia, isto é, de que ela era uma aliada, não o alertou sobre o fato e lhe ocultou dois dados fundamentais: (a) ter sido seu amante no período em que a chilena morou em Buenos Aires, (b) ser o pai do filho dela.

Também não se opôs que os sentimentos do amigo pela bela fossem divulgados pela América Latina em prol da causa revolucionária, isto é, que o amor de Baltasar, através de uma rede de canções, servisse de código para a transmissão de informações obtidas na espionagem por ela. Além disso, comenta a necessidade de se manter a história desse afeto através das músicas populares: "La leyenda de Ofelia y su enamorado platónico, mi amigo Baltasar, debía seguir viva en las vidalitas, las cumbias y los corridos...". ${ }^{43}$ Seu desejo sugere que acredita ser a relação do companheiro e Ofélia parte da história das independências latino-americanas e capaz de dar um tom mais brando à época dos conflitos.

Varela só revela tais fatos ao leitor, esclarecendo que nada será comentado com Bustos ou com qualquer outra pessoa, mantendo-o também sob esse ponto na ignorância. Se a atitude dele intenta preservar o outro de uma sensação de logro ou de desilusões, por outro lado não exclui a hipótese de que se trata de um homem que manipula quem estiver a seu redor. Em outras palavras, é um ser que age nas sombras, sob o manto da amizade e que, por isso, pôde dispor da vida do companheiro conforme lhe convinha. Deste modo, percebemos que os maiores inimigos que a personagem principal precisa vencer não estão do lado dos que lutam a favor da coroa espanhola, mas situam-se bem mais próximos, a saber: ele próprio, a família, os amigos e a amada.

\section{0 término da campanha e o surgimento de horizontes}

Com o término da campanha, uma nova vida se desenha para Baltasar Bustos. Em virtude das experiências passadas, olha para a existência de modo mais maduro e desiludido, pois tem consciência de que as independências foram obtidas, mas que os ideais de liberdade, fraternidade e igualdade ainda estão longe de serem vivenciados pelo povo latino-americano.

Os percalços pelos quais passou, os enganos em que se envolveu e as verdades que desconhece não encerram a obra com um tom pessimista, como poderíamos supor.

43 Idem, p. 258-259. A vidalita é uma canção popular argentina, de tema amoroso e triste, cantada com acompanhamento de violão; o corrido é uma música de origem popular mexicana constituída de narrativa, em compasso composto e cantada em terças paralelas. 


\section{Conexão Letras}

Termina com Baltasar formando sua própria família, gerada durante a campanha: o menino é filho da mulher que perseguiu pela América Latina, e o atual amor, Gabriela, a jovem que conheceu num dos países pelos quais peregrinou.

O porteño sofrera duas decepções com Ofélia Salamanca: o ideal de beleza que formara dela não correspondeu à realidade, e, diferente do que pensara, o fato de ele ter o status de um herói, não alterou a apatia da amada. Todo o esforço dos últimos anos voltados à campanha amorosa fora vão:

Y ella era una mujer de edad indefinida, peinada hacia atrás y con un chongo mal sostenido por horquillas. [...]

\section{Ella nunca le dirigió la mirada. $[\ldots]^{44}$}

A trajetória amorosa do porteño se encerra em definitivo com a chegada de Gabriela Cóo em Buenos Aires, porque fecha o ciclo que ainda estava aberto pela lembrança melancólica de Ofélia. Quanto ao aspecto político, já havia sido concluído com o retorno definitivo de Balta à cidade de origem.

O restabelecimento de Bustos, em solo argentino, ocorre em companhia de mais um amigo, Manuel Bustos, o filho de Ofélia. Essa criança, com pouco mais de dez anos e que se tornara seu pupilo, é o ser no qual Balta se ampara ao retornar para casa e iniciar uma nova existência.

Ao final de uma década de viagens e lutas, Bustos termina sua campanha emocionalmente feliz, mesmo que, antes desse desfecho, estivesse um pouco descrente e receoso quanto ao seu futuro e ao da América Latina, conforme expressa a Dorrego e Varela: "para ser perfectamente sincero, es que todavía hay un buen trecho entre lo que ya viví y lo que me falta por vivir. Se los advierto. No lo voy a vivir en paz. Ni yo, ni la Argentina, ni la América entera..."45

A fala pesarosa acima, do agora ex-revolucionário, deve ser entendida como proferida por um homem que acabou de sair do campo de batalhas, no qual permanecera por mais de uma década, e que se sente deslocado quando inserido novamente na sociedade. Tanto isso é verdade que o discurso feito aos amigos de Buenos Aires exalta não os tempos de paz, mas as coisas que aprendeu durante o período de lutas e contém a referência à saudade dos amigos que conheceu na revolução: "No ha habido momento más fraternal o más gozoso en la historia de América. Qué gratitud haberlo compartido con ellos [Echagüe y Arias]. [...] Guerra e independencia, el respeto a los demás, la justicia y la fe. Sé lo que significan esas cosas." 46

A resolução política fica em aberto, mas, em vista do bom desenrolar da empreitada amorosa, gera a expectativa de que a América Latina terá um futuro próspero e conseguirá se aproximar do sonho do hermano. A espera de que isso se dê está na permanente ligação entre o caráter político e sentimental que sempre ocorreram concomitantes e na permanente certeza que Baltasar teve de que o final que obtivesse em uma das suas campanhas, influenciaria na outra.

Como as ações de Baltasar Bustos tinham por uma das metas a ruptura da ordem política existente na América Latina, a campanha na qual se engajou estava ligada à vida

44 Idem, p. 247-249.

45 Idem, p. 257.

46 Idem, ibidem. 
dos homens na Terra. Ao ganhar o posto de herói, cria-se a expectativa de haver combatido os males conhecidos que afligiam as pessoas, entre eles, a exploração econômica e a dependência a um governo distante. Desse modo, gera, no povo latino-americano, a esperança de uma vida melhor.

Balta e os demais companheiros apontaram que são os próprios homens que alteram o destino, deixando aceso o desejo de que as mudanças, que ocasionaram, acabem por oportunizar uma sociedade mais harmoniosa, sem tantas diferenças entre os indivíduos:

Entretanto, na comparação efetuada entre filosofias da história e milenarismo, é menos a orientação teleológica do tempo que está em causa, que a espera de uma ruptura com o que foi até o presente da história dos homens, e da irrupção brutal de um outro tempo, de um neon no qual os homens seriam definitivamente libertados dos males e dos conflitos que afetaram toda a sua história conhecida. É verdade que certos textos de Marx, notadamente, conferem à revolução a vir o caráter de um acontecimento escatológico, dividindo a história entre um antes - marcado pelo sofrimento, pela miséria e pelas desigualdades - e um depois - momento desvencilhado dos aspectos negativos com os quais se trama a história ordinária, tanto que não podem mais recebe tal qualificação. ${ }^{47}$

Tal como Baltasar, que diante de caminhos percorridos necessitou demonstrar um comportamento diferente, o povo latino-americano deverá perceber que, com as independências obtidas, o mundo conhecido se altera irreversivelmente. A sociedade formada com as transformações ainda não é a idealizada pelas pessoas que desejam habitar um espaço mais harmônico, mas elas precisam aprender a lidar com a nova vida que se apresenta e, assim, seguir em busca e na construção do lugar que as torne felizes.

\section{Referências}

CARLOS FUENTES: estos fueron los palacios. In: Espejo de escritores. Entrevistas feitas por Abel Quesada para The New York Time Magazine. Hanover: del Norte, 1985. p. 81-104.

CARLOS FUENTES: página oficial. [s.d]. <http://www.carlos-fuentes.net.>. Acesso em 23 dez. 2009.

COLLIOT-THÉLÈNE, Catherine. Philosophies de l'histoire et millénarisme. In: COLLOQUE MILLENAIRES, MESSIANISMES ET MILLENARISMES, [s.d], Paris.

Actes... Paris: [s.n], $2^{\text {ème }}$ semestre 1999. p. 311-325.

DUVIOLS, Jean-Paul. Dictionnaire culturel de l'Amérique Latine: pays de langue espagnole. Paris: Ellipses, 2000. p. 379.

FRANCO, Jean; LEMOGODEUC, Jean-Marie. Anthologie de la litterature hispano-

47 COLLIOT-THÉLÈNE, Catherine. Philosophies de l'histoire et millénarisme. In: COLLOQUE MILLENAIRES, MESSIANISMES ET MILLENARISMES, [s.d], Paris. Actes... Paris: [s.n], 2ème semestre 1999. p. 311-325. No texto original, na página 320, lemos: "Toutefois, dans la comparaison effectuée entre philosophies de l'histoire et milenarisme, c'est moins l'orientation téléologique du temps qui est en cause, que l'attente d'une rupture avec ce que fut jusqu'à présent l'histoire des hommes, et de l'irruption brutale d'un autre temps, d'un nouvel eon, dans lequel les hommes seraient définitivement délivrés des maux et des conflits qui ont affecté toute leur histoire connue. Il est vrai que certains textes de Marx, notamment, confèrent à la révolution à venir le caractère d'un évènement escathologique, partageant l'histoire entre un avant marqué par la souffrance, la misère et les inégalités, et un après, à ce point affranchi du négatif dont se trame l'histoire ordinaire qu'il ne peut plus même en porter le nom." 


\section{Conexão Letras}

americaine du XX siècle. Paris: PUF, 1993.

FUENTES, Carlos. La campaña. México: Fondo de Cultura Económica, 1990.

MAGASICH-AIROLA, Jorge; BEER, Jean-Marc de. As regiões do ouro. In: América mágica: quando a Europa da Renascença pensou estar conquistando o Paraíso. Tradução de Regina Vasconcellos. São Paulo: Paz e Terra, 2000. p. 113- 153.

MENTON, Seymour. Crónica de uma guerra denunciada: “La campaña” de Carlos Fuentes. In: _. La nueva novela histórica de la América Latina 1979-1992. México: Fondo de Cultura Económica, 1993.

NOUHAUD, Dorita. Eldorado. In: BRUNEL, Pierre. (Org.) Dicionário de mitos literários. 2. ed. Tradução de Carlos Sussekind et al. Rio de Janeiro: José Olympio, 1998. p. 315-318.

PERKOWSKA-ALVAREZ, Magdalena. Un realismo censurado: la poética del des/engaño en La campaña de Carlos Fuentes. CRICCAL: les nouveaux réalismes - autre réel, autre écriture. Paris, $2^{\text {ème }}$ série, n. 25, p. 95-103, $4^{\text {ème trim. } 2000 .}$

PESSIN, Alain. Le retour de l'utopie. L'imaginaire utopique aujoud'hui. Paris: PUF, 2001.

POMER, Leon. As independências na América Latina. Tradução de Rubens Eduardo Ferreira Frias. São Paulo: Brasiliense, 1999. 